\title{
Aortic root replacement with Freestyle stentless valve for complex aortic root infection
}

\author{
Toshihiro Fukui, MD, Shigefumi Suehiro, MD, Toshihiko Shibata, MD, Koji Hattori, MD, Hidekazu Hirai, MD, and
}

Takanobu Aoyama, MD, Osaka, Japan

A

ortic valve replacement in the presence of infectious endocarditis with an aortic annular abscess, aortic root destruction, and left ventricular-aortic discontinuity, remains a formidable surgical challenge. Early diagnosis and surgical intervention can be lifesaving. ${ }^{1-3}$ Radical débridement of infected tissues and reconstruction of the left ventricular outflow tract are fundamental tenets of treatment. However, the choice of valve substitute remains one of the most contentious subjects in the management of this condition. Although several researchers ${ }^{3-6}$ have reported success with homografts and autografts, prosthetic valve replacement remains the standard surgical approach. ${ }^{7-9}$

Recently the porcine stentless bioprosthesis has gained favor as an aortic valve replacement because its hemodynamic performance is excellent and it has good midterm durability. ${ }^{10-12}$ We have used this prosthesis in 5 patients with complex aortic root infection during the past 3 years, and that experience is the basis of this report.

\section{Patients and Methods (Table 1)}

We treated 5 patients, 2 men and 3 women (aged 42 to 73 years), who underwent stentless valve replacement for infectious endocarditis involving the native valve $(n=1)$ or a prosthetic valve $(n=4)$ between October 1998 and September 2001. Two patients with prosthetic valve endocarditis had been operated on twice previously. Recurrent prosthetic valve endocarditis (case 1) or perivalvular leakage (case 4) was the indication for the second operation. In case 4 , saphenous vein grafting to the right coronary artery was also performed. In case 2 , the Bentall operation and triple coronary artery bypass grafting had been conducted previously. Three mechanical valves and one stented bioprosthesis had been used, and the mean interval between the previous and current operation was 28.5 months (range 2-61 months) in the patients with prosthetic valve endocarditis.

One patient underwent surgery after inflammation had subsided in response to medical treatment. The other 4 patients were critically ill at the time of operation. The operation was postponed 2

\footnotetext{
From the Department of Cardiovascular Surgery, Osaka City University Medical School, Osaka, Japan.

Received for publication Jan 23, 2002; accepted for publication April 15, 2002.

Address for reprints: Toshihiro Fukui, MD, Department of Cardiovascular Surgery, Osaka City University Medical School, 1-4-3 Asahi-machi, Abeno-ku, Osaka 545-8585, Japan (E-mail: tm-fukui@gem.hi-ho.ne.jp).

J Thorac Cardiovasc Surg 2003;125:200-3

Copyright $\odot 2003$ by The American Association for Thoracic Surgery $0022-5223 / 2003 \$ 30.00+0$

doi: $10.1067 / \mathrm{mtc} .2003 .117$
}

weeks because of a hemorrhagic cerebral infarction in 1 case (case 4). In that case, the patient had been febrile for 1 week and had lost consciousness acutely while in the outpatient department. Cardiopulmonary resuscitation was started immediately, and catheterization, performed under percutaneous cardiopulmonary support and intra-aortic balloon pumping, revealed a stuck valve leaflet and massive aortic regurgitation. She was transferred to the operating room immediately.

Surgical management. A median sternotomy was created, and cardiopulmonary bypass was established with mild systemic hypothermia. The left ventricle was vented by cannulation through the right superior pulmonary vein. Cold blood cardioplegic solution was administered both antegrade and retrograde during aortic clamping. The surgical strategy was débridement of the abscess cavity and all friable tissue, reconstruction of the left ventricular outflow tract, and full root implantation with the Freestyle stentless valve (Medtronic, Inc, Minneapolis, Minn) with coronary reconstruction.

\section{Results}

Microbiology. The causative microorganism was isolated in 3 cases. Coagulase-negative Staphylococcus was cultured in 2 cases, and group B Streptococcus was cultured in another case. The infecting agent could not be identified in the final 2 cases.

Echocardiographic findings. Transesophageal echocardiography was performed preoperatively in all cases except for case 4, a patient whose unstable hemodynamic condition precluded examination. A pseudoaneurysm was detected in 2 of these cases (cases 1 and 2; Figure 1), and an aortic root abscess was demonstrated clearly in the other 2 (cases 3 and 5).

Operative findings and surgical procedures (Table 2). Valve or valved conduit dehiscence with extreme disruption of the entire aortic anulus was found in cases 1 and 2. A pseudoaneurysm was detected on the posterolateral aspect of the fibrous curtain between the aortic valve and the anterior mitral leaflet. The valve ring and aneurysmal cavity were débrided of all friable tissues, and the Freestyle valve was implanted with the full root technique. The proximal anastomosis was accomplished with simple interrupted sutures of 3-0 braided polyester. The sutures were placed in the left ventricular outflow tract, including the ventricular septum and the anterior mitral valve anulus or leaflet. The distal end of the bioprosthesis was sewn end to end to the remnant of the composite graft (case 2) or to the interposition artificial graft (case 1) with continuous 3-0 polypropylene suture. The coronary arteries were reconstructed by triple coronary artery bypass grafting (case 1) or interposition grafting to the previously implanted saphenous vein graft (case 2).

In the other 3 cases, aortotomy revealed extensive inflammation of the entire aortic anulus, vegetations, and an annular abscess. Prosthetic valves were partially detached along the site of the 
TABLE 1. Demographic and preoperative clinical characteristics of patients with complex aortic root infection

\begin{tabular}{|c|c|c|c|c|c|c|c|}
\hline & Age & & & & Transesophageal & & \\
\hline Case & (y) & Sex & Aortic valve history & Condition of patient & echocardiographic findings & Results of cultures & Antibiotics \\
\hline 1 & 42 & $\mathrm{~F}$ & $\begin{array}{l}\text { Infectious endocarditis, } \\
\text { bicuspid; } 2 \text { operations; } \\
\text { Medtronic Hall* valve } 2 \\
\text { mo earlier }\end{array}$ & $\begin{array}{l}\text { Aortic regurgitation, } \\
\text { severe congestive } \\
\text { heart failure, high } \\
\text { fever, cerebral } \\
\text { emboli }\end{array}$ & $\begin{array}{l}\text { Pseudoaneurysm, perivalvular } \\
\text { leak }\end{array}$ & Negative & $\begin{array}{l}\text { Imipenem and } \\
\text { cilastatin, } \\
\text { streptomycin } \\
\text { (28 d) }\end{array}$ \\
\hline 2 & 71 & M & $\begin{array}{l}\text { Annuloaortic ectasia, } \\
\text { ischemic heart disease; } \\
\text { Bentall plus coronary } \\
\text { artery bypass grafting } 1 \text { y } \\
\text { earlier (St Jude Medical } \\
\text { valvet) }\end{array}$ & Infection controlled & $\begin{array}{l}\text { Pseudoaneurysm, no aortic } \\
\text { regurgitation }\end{array}$ & $\begin{array}{l}\text { Coagulase- } \\
\text { negative } \\
\text { Staphylococcus } \\
\text { ((blood) }\end{array}$ & $\begin{array}{l}\text { Imipenem and } \\
\text { cilastatin, } \\
\text { vancomycin } \\
(28 \mathrm{~d})\end{array}$ \\
\hline 3 & 51 & & $\begin{array}{l}\text { Aortic regurgitation, } \\
\text { bicuspid; native valve }\end{array}$ & $\begin{array}{c}\text { Aortic regurgitation, } \\
\text { congestive heart } \\
\text { failure, high fever }\end{array}$ & $\begin{array}{l}\text { Severe aortic regurgitation, } \\
\text { vegetations, root abscess }\end{array}$ & Negative & $\begin{array}{l}\text { Ceftazidime } \\
\qquad(4 \mathrm{~d})\end{array}$ \\
\hline 4 & 69 & $\mathrm{~F}$ & $\begin{array}{l}\text { Aortic stenosis, bicuspid; } 2 \\
\text { operations; aortic valve } \\
\text { replacement (St Jude } \\
\text { Medical valvet) and } \\
\text { saphenous vein graft to } \\
\text { right coronary artery } 5 \text { y } \\
\text { earlier }\end{array}$ & $\begin{array}{l}\text { Shock, intra-aortic } \\
\text { balloon pump and } \\
\text { percutaneous } \\
\text { cardiopulmonary } \\
\text { support }\end{array}$ & Not performed & $\begin{array}{l}\text { Coagulase- } \\
\text { negative } \\
\text { Staphylococcus } \\
\text { (vegetation) }\end{array}$ & None \\
\hline 5 & 73 & $\mathrm{~F}$ & $\begin{array}{l}\text { Aortic stenosis, bicuspid; } \\
\text { bioprosthesis } 7 \text { mo earlier }\end{array}$ & $\begin{array}{l}\text { Aortic regurgitation, } \\
\text { congestive heart } \\
\text { failure, high fever, } \\
\text { cerebral emboli }\end{array}$ & $\begin{array}{l}\text { Perivalvular leak, root abscess, } \\
\text { vegetations }\end{array}$ & $\begin{array}{l}\text { Streptococcus } \\
\quad \text { (blood) }\end{array}$ & $\begin{array}{l}\text { Penicillin } G \text {, } \\
\text { tobramycin } \\
(14 \mathrm{~d})\end{array}$ \\
\hline
\end{tabular}

*Medtronic, Inc, Minneapolis, Minn.

tSt Jude Medical Inc, Minneapolis, Minn.

abscess formation. In case 4, vegetations under the prosthetic valve had caused the valve leaflet to become stuck in the open position. In case 5, a para-annular abscess in the region of the noncoronary sinus communicated with the right atrium. A large vegetation attached to the orifice was removed, and the opening of the fistula was closed. Native valve and prosthetic valves were removed, followed by aggressive débridement. The abscess cavity in each patient was closed with a bovine pericardial patch, and the aortic root was reconstructed with the Freestyle valve. Inflow anastomosis sutures in the reconstructed anulus were placed with deep bites to attach the left ventricle to the patch. Thus the Freestyle valve was seated in the left ventricular outflow tract, and the closed abscess cavity was outside the valve itself. The coronary arteries were implanted as buttons to the side to the corresponding sinus of the bioprosthesis with a continuous 4-0 polypropylene suture. In case 3, a saphenous vein graft to the right coronary ostium was performed because a bicuspid valve made direct implantation of the coronary artery inadvisable.

The mean perfusion time was 366 minutes (range 239-520 minutes). The mean aortic crossclamp time was 199 min (range 155-246 minutes).

Operative results. There were no early or late deaths in this series. Low cardiac output necessitated postoperative intra-aortic balloon pump support in 1 case. In case 4, immediate sternal closure was precluded by low cardiac output at the time of surgery, and the sternum was closed uneventfully on the sixth postoperative day. Complete atrioventricular block, which did not necessitate pacemaker implantation, developed in 1 patient. No patients required reexploration for postoperative bleeding.

All patients received intravenous antibiotic therapy for at least for 4 weeks after the operation. Signs of inflammation subsided and disappeared completely, and all patients are alive and well without evidence of recurrent infection (Table 2).

\section{Discussion}

Untreated infectious endocarditis with aortic annular abscess, aortic root destruction, and left ventricular-aortic discontinuity is invariably fatal. Immediate surgical intervention can be lifesaving, but the mortality rate after this heroic intervention can be as high $21 \% .{ }^{13}$ For patients with complex aortic root infection, simple replacement of the infected valve is inadequate treatment, and a more extensive operation is indicated.

Several innovative surgical techniques have been developed to manage aortic root infection, such as patch closure of the abscess and in situ valve replacement, ${ }^{14}$ translocation of the aortic valve and saphenous vein bypass grafts to the coronary arteries, ${ }^{15}$ and 

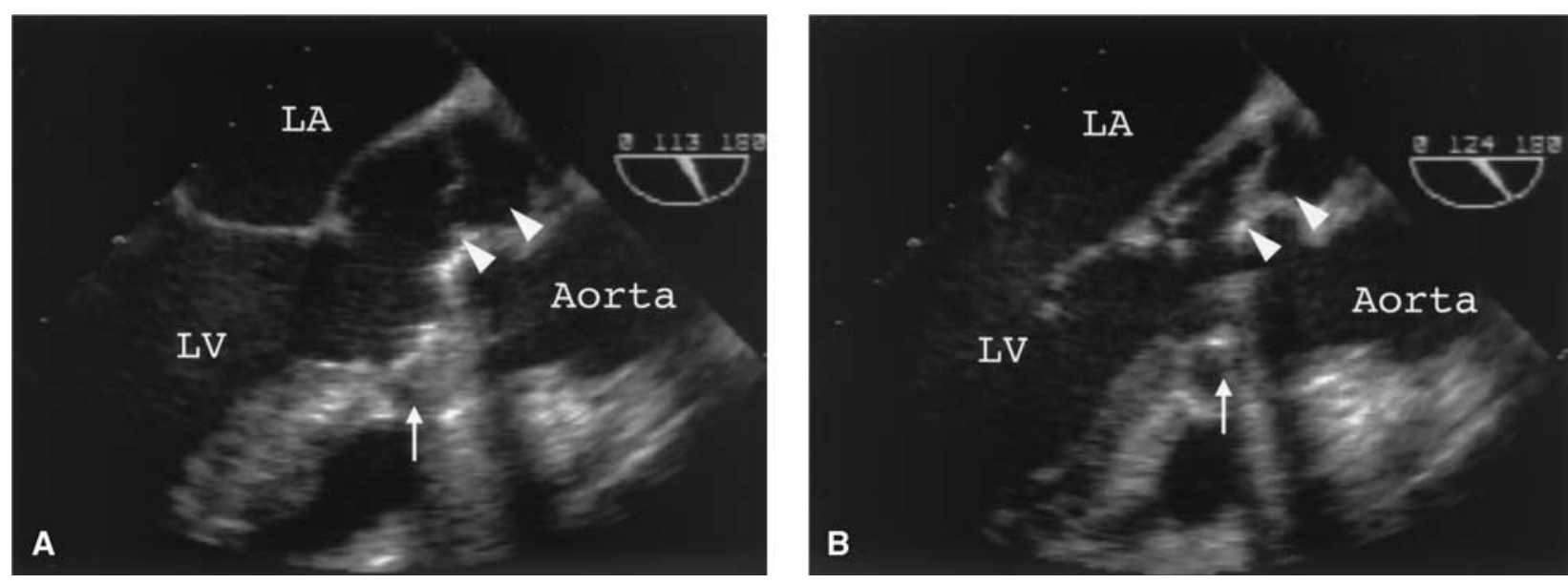

Figure 1. Transesophageal echocardiogram showing pseudoaneurysm and perivalvular leak in patient with infectious endocarditis and prosthetic aortic valve. Arrow indicates prosthetic valve; arrowheads identify pseudoaneurysm causing left ventricular-aortic discontinuity. $L A$, Left atrium; $L V$, left ventricle. A, Systolic phase. $B$, Diastolic phase.

TABLE 2. Intraoperative and postoperative data on patients undergoing aortic root replacement with the Freestyle stentless valve for complex aortic root infection

\begin{tabular}{|c|c|c|c|c|c|c|c|c|}
\hline Case & Operative findings & $\begin{array}{l}\text { Abscess } \\
\text { closure }\end{array}$ & $\begin{array}{l}\text { Valve size } \\
\quad(\mathrm{mm})\end{array}$ & Coronary reconstruction & Postoperative course & Antibiotics used & Results & $\begin{array}{c}\text { Follow-up } \\
(\mathrm{mo})\end{array}$ \\
\hline 1 & $\begin{array}{l}\text { Pseudoaneurysm } \\
\text { (NCC), severe } \\
\text { valve dehiscence }\end{array}$ & No & 27 & $\begin{array}{l}\text { Triple coronary artery } \\
\text { bypass grafting }\end{array}$ & $\begin{array}{l}\text { Low output syndrome } \\
\text { requiring intra-aortic } \\
\text { balloon pump }\end{array}$ & $\begin{array}{l}\text { Imipenem and } \\
\text { cilastatin, } \\
\text { flomoxef, } \\
\text { streptomycin; } \\
6 \text { wk }\end{array}$ & Alive & 39 \\
\hline 2 & $\begin{array}{l}\text { Pseudoaneurysm } \\
\text { (NCC), valved } \\
\text { conduit } \\
\text { dehiscence }\end{array}$ & No & 29 & $\begin{array}{l}\text { Saphenous vein graft } \\
\text { (RCA) }\end{array}$ & No complications & $\begin{array}{l}\text { Vancomycin, } \\
\text { imipenem and } \\
\text { cilastatin; } \\
5 \text { wk }\end{array}$ & Alive & 29 \\
\hline 3 & $\begin{array}{l}\text { Root abscess } \\
\text { (commissure } \\
\text { between LCC } \\
\text { and RCC) }\end{array}$ & Yes & 23 & $\begin{array}{l}\text { LCA; button RCA; } \\
\text { saphenous vein graft }\end{array}$ & No complications & $\begin{array}{l}\text { Penicillin G, } \\
\text { tobramycin; } \\
5 \text { wk }\end{array}$ & Alive & 17 \\
\hline 4 & $\begin{array}{l}\text { Stuck valve leaflet } \\
\text { from vegetations, } \\
\text { root abscess } \\
\text { (RCC) }\end{array}$ & Yes & 19 & Button LCA; & $\begin{array}{l}\text { Low output syndrome, } \\
\text { delayed sternal } \\
\text { closure, complete } \\
\text { atrioventricular block }\end{array}$ & $\begin{array}{l}\text { Fosfomycin, } \\
\text { vancomycin; } \\
4 \text { wk }\end{array}$ & Alive & 4 \\
\hline 5 & $\begin{array}{l}\text { Root abscess (RCC } \\
\text { and half of NCC), } \\
\text { aorta-right atrium } \\
\text { fistula }\end{array}$ & Yes & 19 & Button LCA; button RCA & No complications & $\begin{array}{l}\text { Penicillin G, } \\
\text { tobramycin; } \\
4 \text { wk }\end{array}$ & Alive & 4 \\
\hline
\end{tabular}

$N C C$, Noncoronary cusp; $R C A$, right coronary artery; $L C C$, left coronary cusp; $R C C$, right coronary cusp; $L C A$, left coronary artery.

composite prosthesis and Dacron polyester fabric graft reconstruction of the aortic root. ${ }^{16}$ Despite the success obtained with these methods, some researchers have reported the superiority of autograft and homograft valve replacement for complex aortic valve endocarditis. ${ }^{3-6}$
Aortic homografts and autografts (Ross procedures) have been used for infectious endocarditis because these grafts mold well to the fragile infected aortic anulus, ${ }^{3,17}$ offer excellent hemodynamic performance, ${ }^{18}$ and are resistant to infection. Aortic homografts offer an attractive alternative to the implantation of prosthetic 
material. However, homografts are not always available and are particularly difficult to obtain in Japan. Further, the Ross operation is complicated, and it is not an option in urgent situations. ${ }^{9}$ Recently, stentless porcine valves have been used to treat infectious endocarditis. ${ }^{19,20}$ Santini and colleagues ${ }^{19}$ reported a series of 10 cases of aortic valve infective endocarditis treated with porcine stentless valve (Biocor LTDA, Biocor Industriae e Pesquisa LtDa, Belo Horizonte, Brazil; Toronto SPV, St Jude Medical, Inc, St Paul, Minn).

Our surgical strategy for managing complex aortic endocarditis is full root replacement with the Freestyle stentless valve after extensive débridement of infected tissue, with closure of abscess as indicated. Patch closure of a periannular abscess and destroyed anulus permits obliteration of these cavities and facilitates reconstruction of the left ventricular outflow tract. The Freestyle stentless valve resembles an aortic homograft, and its handling qualities are similar to those of a homograft. We found it relatively easy to insert the Freestyle stentless valve into the left ventricular outflow tract, including the reconstructed aortic anulus. The technique that we used protected the débrided area by excluding it from exposure to systemic pressure. Radical débridement is absolutely essential to the eradication of infection. ${ }^{7,21}$ Full root replacement with the Freestyle valve allows the surgeon greater confidence in performing radical débridement of all infected tissue, because prosthetic replacements for the structures integral to the left ventricular outflow tract are readily available. The Freestyle stentless valve with the full root replacement method offers the cardiac surgeon a new and powerful, option for treating complex aortic root infection. Our operative results were favorable, although the number of cases was small. Reinfection and valve dysfunction were not complications, and hemodynamic performance has been excellent. ${ }^{22,23}$ Although long-term follow-up is necessary to determine its durability, the Freestyle stentless valve appears to be an excellent alternative to a homograft.

\section{References}

1. David TE, Komeda M, Brofman PR. Surgical treatment of aortic root abscess. Circulation. 1989;80:I269-74.

2. d'Udekem Y, David TE, Feindel CM, Armstrong S, Sun Z. Long-term results of operation for paravalvular abscess. Ann Thorac Surg. 1996; 62:48-53.

3. Niwaya K, Knott-Craig CJ, Santangelo K, Lane MM, Chandrasekaran K, Elkins RC. Advantage of autograft and homograft valve replacement for complex aortic valve endocarditis. Ann Thorac Surg. 1999; 67:1603-8

4. Lau JK, Robles A, Cherian A, Ross DN. Surgical treatment of prosthetic valve endocarditis: aortic root replacement using a homograft. J Thorac Cardiovasc Surg. 1984;87:712-6.

5. Haydock D, Barratt-Boyes B, Macedo T, Kirklin JW, Blackstone E. Aortic valve replacement for active infectious endocarditis in 108 patients: a comparison of freehand allograft valves with mechanical prostheses and bioprostheses. J Thorac Cardiovasc Surg. 1992;103: 130-9.

6. Kirklin JK, Kirklin JW, Pacifico AD. Aortic valve endocarditis with aortic root abscess cavity: surgical treatment with aortic valve homograft. Ann Thorac Surg. 1988;45:674-7.

7. Bauernschmitt R, Jakob HG, Vahl CF, Lange R, Hagl S. Operation for infective endocarditis: results after implantation of mechanical valves. Ann Thorac Surg. 1998;65:359-64.

8. Bauernschmitt R, Vahl CF, Lange R, Jakob HG, Hagl S. Surgical treatment of acute endocarditis of the aortic valve with paravalvular abscess: considerations justifying mechanical replacement devices. Eur J Cardiothorac Surg. 1996;10:741-7.

9. Aagaard J, Andersen PV. Acute endocarditis treated with radical debridement and implantation of mechanical or stented bioprosthetic devices. Ann Thorac Surg. 2001;71:100-4.

10. David TE, Puschmann R, Ivanov J, Bos J, Armstrong S, Feindel CM, et al. Aortic valve replacement with stentless and stented porcine valves: a case-match study. J Thorac Cardiovasc Surg. 1998;116:236-41.

11. Yun KL, Sintek CF, Fletcher AD, Pfeffer TA, Kochamba GS, Hyde MR, et al. Aortic valve replacement with the Freestyle stentless bioprosthesis: five-year experience. Circulation. 1999;100(Suppl 19): II-17-23.

12. Westaby S, Horton M, Jin XY, Katsumata T, Ahmed O, Saito S, et al. Survival advantage of stentless aortic bioprostheses. Ann Thorac Surg. 2000;70:785-91.

13. Watanabe G, Haverich A, Speier R, Dresler C, Borst HG. Surgical treatment of active infective endocarditis with paravalvular involvement. J Thorac Cardiovasc Surg. 1994;107:171-7.

14. Symbas PN, Vlasis SE, Zacharopoulos L, Lutz JF. Acute endocarditis: surgical treatment of aortic-left ventricular discontinuity. J Thorac Cardiovasc Surg. 1982;84:291-6.

15. Reitz BA, Stinson EB, Watson DC, Baumgartner WA, Jamieson SW. Translocation of the aortic valve for prosthetic valve endocarditis. J Thorac Cardiovasc Surg. 1981;81:212-8.

16. Frantz PT, Murray GF, Wilcox BR. Surgical management of left ventricular-aortic discontinuity complicating bacterial endocarditis. Ann Thorac Surg. 1980;29:1-7.

17. Vesely I, Gonzales-Lavin L, Graf D, Boughner D. Mechanical testing of cryopreserved aortic allografts. J Thorac Cardiovasc Surg. 1990; 99:119-23.

18. Hasegawa J, Kitamura S, Niwaya K, Kawachi K, Kawata T, Kameda Y. Echocardiographic characteristics of the cryopreserved allograft aortic valve replacement assessed by intraoperative transesophageal echocardiography. Cardiovasc Surg. 1996;4:293-8.

19. Santini F, Musazzi A, Bertolini P, Pugliese P, Fabbri A, Faggian, et al. Stentless porcine bioprosthesis in the treatment of aortic valve infective endocarditis. J Card Surg. 1995;10:205-9.

20. Sakaguchi T, Sawa Y, Ohtake S, Hirata N, Matsuda H. The Freestyle stentless bioprosthesis for prosthetic valve endocarditis. Ann Thorac Surg. 1999;67:533-5.

21. Baumgartner FJ, Omari BO, Robertson JM, Nelson RJ, Pandya A, Pandya A, et al. Annular abscesses in surgical endocarditis: anatomic, clinical, and operative features. Ann Thorac Surg. 2000;70:442-7.

22. Thomson HL, O'Brien MF, Almeida AA, Tesar PJ, Davison MB, Burstow DJ. Haemodynamics and left ventricular mass regression: a comparison of the stentless, stented and mechanical aortic valve replacement. Eur J Cardiothorac Surg. 1998;13:572-5.

23. Silberman S, Shaheen J, Merin O, Fink D, Shapira N, Liviatan-Strauss $\mathrm{N}$, et al. Exercise hemodynamics of aortic prostheses: comparison between stentless bioprostheses and mechanical valves. Ann Thorac Surg. 2001;72:1217-21. 